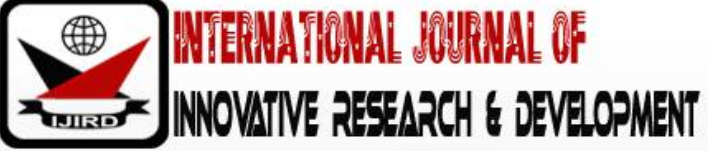

ISSN 2278 - 0211 (Online)

\section{Antecedent Factors That Motivated People to Be Successful in Science: The Case of Wa District of the Upper West Region, Ghana}

Saviour V. K. Adjibolosoo
Lecturer, Department of Science, Presbyterian College of Education, Ghana
Stephen T. Annan
Lecturer, Department of Science, College of Education, Ghana
Emmanuel Ow usu
Lecturer, Department of Science, Presbyterian College of Education, Ghana
Twumasi, A.K.
Lecturer, Department of Science Education, University of Education, Ghana

\begin{abstract}
:
Introduction: The misconception held by many Senior High Schools Students that Science is difficult is having a spill-over effects on many of the Junior High School (JHS) graduates. Many of these JHS graduates were not and still are not opting for science courses at the Senior High Level because they have been indoctrinated with the notion that science is difficult. Objective: The objective of this study was to explore the factors that have motivated some personalities to become successful in the fields of science and use the results to encourage more JHS graduates to opt for science courses. Methodology: The study was conducted in the Wa District of the Upper West Region (UWR) of Ghana. Self-reported data were collected from 40 successful science-achievers using structured questionnaire. Purposive sampling technique was used to select the sample. Analysis: The data collected was analyzed using descriptive statistics and One-way ANOVA. Results: The results of the study revealed that teachers and parents in addition to role models constitute the key variables motivating personalities to read science. Analysis of variance shows statistical significant difference between the following variables: rural and urban motivational factors (mean square $=1.469 ; \mathrm{F}=6.723 ; \mathrm{p}=0.013$ ); personalities who influence choice of science (mean square=17.778; $\mathrm{f}=49.231 ; \mathrm{p}=0.000$ ); reasons for choice of science (mean square $=20.069 ; \mathrm{F}=49.828 ; \mathrm{p}=0.000$ ); how respondents were motivated by parents, teachers, and classmates (mean square=19.136; $\mathrm{F}=26.310 ; \mathrm{p}=0.000$ ); parental educational background and motivation (mean square $=13.225 ; \mathrm{F}=10.309 ; \mathrm{p}=0.003$ ); suggested ways to motivate students to read science (mean square=24.544; $\mathrm{F}=28.649 ; \mathrm{p}=0.000$ ); influence of role models on respondents education (mean square=26.678; $f=24.298 ; p=0.000$ ); professions of respondents role models (Mean square=36.736; $F=28.128 ; p=0.000$ ); and ways respondents managed the problems they encountered whilst in school (mean square=40.00; $F=28.148 ; p=$ 0.000).Recommendations: The study recommends that teachers and parents should collaborate when making decision regarding choice of courses for their wards. Career education must be instituted in the JHS to give students first-hand information on career opportunities to help them make informed decisions on their choice of courses. Teachers and doctors must exhibit good character worth emulating as they were identified as key role models motivating students to read science. Furthermore, teachers must practicalise their classroom teaching and learning activities to motiva te students to read science.
\end{abstract}

Keywords: Science-achievers, motivation, WA district, upper west region, Ghana

\section{Introduction}

The world is becoming scientific Village and everything depends on the application of science and technology. There is no doubt that Science and Technology have created and are still shaping the structure of our modern world. According to Seitz (1978),Science which started out primarily as an adventure of the mind is now becoming one of the principal pillars of life. Science and Technology have brought within the reach of multitudes benefits and advantages which only a short time ago were the privilege of the few. They have shown how malnutrition, hunger and diseases could be overcome. Scientific truths have freed people from many false ideas and the practical application of scientific truths in industry as well as in the fields of communication and transportation, has freed people from unnecessary drudgery and, to a degree, from the limitations of time and distance. Scientific truths applied in preventive medicine and health care have helped free people from premature death or a morbid fear of disease.

It is therefore very important that all citizens should understand the basic scientific culture produced by modern civilization. Natural phenomena and their accompanying effects must be understood by all citizens so that misconceptions and superstitions and their associated fears are laid (diSessa, 2006; Linn, 2006). The understanding of the phenomena is 
also an important weapon in the struggle to remove diseases, poverty and increase food production in order to raise the standard of living for all.

Every individual needs to know more about how science works and the implications of science. With these, they would be in better position to have greater control over their environment. This demand for science was again emphasized by DeBoer (1991). According to him, everyone who lives in the world needs to have some understanding of the nature and effects of science, this seems to be the only way to avoid expensive, undesirable and disastrous development. If these challenges are to be met, the inculcation of the scientific attitudes and popularization of science are important to all individuals. With this increasing emphasis on science as a tool for life, many nations including Ghana are seriously responding to pressure to get every individual enrolled into the scientific community.

In Ghana, however, many students at the pre-university level often complain that science is difficult. This misconception has long been noted to be a universal problem and for that matter a national school problem in Ghana and particularly observed among many students in the JHS.

However, some personalities have studied science and became successful science-achievers. What might have been the underlying motivational factors behind their success? Could it be their own personal efforts, some external agents or both? In fact, if science is to be studied by all and up to the tertiary level, these questions need to be answered and the results used to encourage others.

Literature reviewed indicates no concrete answer to these questions. This research is therefore aimed at finding out the key motivational factors that have contributed to the success of these successful science-achievers and also to use the data obtained to encourage and sustain the interest of others especially those in the JHS to offer science and continue with it to higher level.

\section{Literature Reviewed}

\subsection{Concept of Motivation}

Motivation has been given many interpretations by various writers but it appears they all seem to agree to the same view. Motivation, according to Ingule (1996) deals with 'why'" of behaviour. That is, it addresses itself to the question of why an individual does what he or she does.

From historical perspective, motivation according to Chauhan (1978) comes from the Latin root moveers which means "to move". Thus in its literal meaning, motivation is the process of arousing movement in an organism. This movement is produced and regulated through the release of energy within the tissues. Motivation according to Bruner (1966) connotes a "will, the volitional or dynamic aspect of behaviour, presumably dependent variously on physiological, psychological and environmental factors. The Oxford Dictionary of Current English also defined motivation as what induces a person to act in a particular way."

It is the contention of Bernand (1966) that motivation is all those phenomena which are involved in the stimulation of action towards particular objectives where previously there was little or no movement toward those goals. A careful examination of the above definitions of motivation leads to a number of ideas about the concept. It creates energy, drive, stimulation excitement, arousal and activation; it involves certain forces acting on or within a person to initiate and direct behaviour; it involves guiding, directing or channeling the energies created towards the achievements of goals. The above concept of motivation suggests that when students perceive high education to be of value to them they would put in maximum efforts in their education so as to attain high level.

Motivation has been categorized into two types. Intrinsic and Extrinsic. Intrinsic motivation consists of those needs, wants, and desires and so on, which exists within the individual. Intrinsic motivation therefore stems from natural innate or inherent motives. It is self-drive and has the advantage of fostering greater independence and initiative in action. Extrinsic motivation stems from external stimulation and events. It is controlled by a system of incentives, rewards and punishments. This implies that when a student is motivated either intrinsically or extrinsically or both, he or she would study harder and do well in schools.

\subsection{Theoretical Basis of the Study}

A number of theories have been propounded to explain how people are motivated. Five of these theories which are relevant to the present study include Maslow's hierarchy of needs theory; achievement motivation theory; competence motivation theory; curiosity motivation theory; and incentive motivation theory.

\subsubsection{Maslow's Hierarchy Needs Theory}

According to Maslow's hierarchy needs theory (1954), the traditional approach of pain avoidance, pleasure seeking and tension reduction are the major sources of motivating behaviour. He suggested that there is a definite order in which individuals attempt to satisfy their needs. Maslow sees this order of importance as universal among human beings. Furthermore, he maintains that a person will remain at a given need level until those needs are satisfied. At the most basic level are physiological needs, Maslow contends until these needs are at least partially satisfied, the individual will not be concerned with the needs of the next level. Information in Table 1 summarized Maslow's needs hierarchy. 


\begin{tabular}{|c|c|}
\hline Levels of Motivational & Needs \\
\hline Physiological Needs & Food, drink, sex, shelter \\
\hline Safety Needs & $\begin{array}{c}\text { Security, order, protection, stability, dependency, } \\
\text { freedom from chaos and fear. }\end{array}$ \\
\hline Love Needs & Affection, group affiliation and personal acceptance \\
\hline Self-esteem Needs & $\begin{array}{c}\text { Self-respect, prestige, reputation, competence, } \\
\text { confidence and social status. }\end{array}$ \\
\hline Self-actualization Needs & $\begin{array}{c}\text { Self-fulfillment, achievement of personal goals, } \\
\text { ambitions and talent. }\end{array}$ \\
\hline
\end{tabular}

Table 1: Summary of Maslow's Needs Hierarchy

Concerning the above need hierarchy (Table 1), Maslow does not mean to imply that every human being achieves full success in satisfying all the needs. What he means is that persons cannot consider some of their more social needs when their basic needs are left unfulfilled. The Maslow's Hierarchy Needs Theory therefore suggests to the present study that a person can be motivated to attain higher standard in education if his or her basic needs are satisfied. This implies that children who are better nourished and better cared for will avail themselves more often in educational attainment. Also, children who are reared in an atmosphere of peace, warmth and acceptance would do better in school than their counterparts who are brought in an atmosphere of unsupportive or cold.A study conducted by Agyeman (1986) supports this view. He observed that poverty negatively affects the chances of success of children in school. He explains that children who are constantly hungry will have difficulty in paying attention to a lesson in the classroom and this affects their studies and thus lowers their educational attainment.

\subsubsection{Another Motivational Theory That Explains How Individuals Are Motivated Is Achievement Motivation Theory}

This is a psychological motive that evolves out of basic intrinsic motivation. It involves the desire to perform in terms of standard of excellence, to do something better or more efficiently, to solve problems, to master complex tasks or to be successful in competitive situations. Achievement motive therefore aims at emphasizing a high level of ability and avoiding any display of low ability. Rosen shire (1980) observed that children show higher level of achievement when teachers spend larger amount of time in the direct teaching of mathematics, science and social studies than in other subjects. A research by Hummel and Sprinthall (1965) indicates that academic achievement depends on individual's ego, strength or reality orientation. The study demonstrated that under-achievers possess weak ego while higher achievers possess strong ego. People with high need for achievement generally choose tasks of moderate probability of success. They are not upset by failure at such tasks; they seem greatly gratified by success. Individuals with high fear of failure often choose very difficult or very easy tasks; they are assured of success at the easy ones and they are not blamed for failure at the difficult ones (Atkinson and Litwin, 1960). Equally important factor which affects how much individuals strive to succeed in learning is their desire to maintain a positive self-evaluation. People put extra effort into tasks that are important to their self-definitions. Their tendency to do this is explained by a model of self-evaluation maintenance (SEM) (Tesser, 1988). The SEM proposes that self-evaluation may sometimes be raised or lowered through a comparison process (Masters and Kiel, 1987) To them, this happens when a personal performance is compared with the performance of a close friend on a skill or task that is important to one's self-definition. According to Tesser and Campbell (1985), people strive to achieve a level that other people who are close to them have achieved.

The above views on the need for achievement suggest that when students are engaged in learning experiences in which they have an effect on their environment a curiosity motivation is developed in them for continual strive for attainment of perfection for good work and for high educational achievement. Also, the view of Tesser and Campbell (1985) that people strive to achieve a level that other people who are close to them have achieved suggests that role model has a significant influence on the educational attainment of children. Another suggestion from the above theory is that people became motivated when they engaged in tasks which are challenging and attainable. This implies that when students are engaged in learning experiences that challenge their achievement motive they become intrinsically motivated and therefore strive hard to achieve success. This is because success is felt and interest generated when one has a challenging goal and achieves it.

\subsubsection{Competence Motivation Theory}

Propounded by White (1959), the theory suggested that one of the most fundamental human motive is based on strong personal desire to master one's environment. This he refers to as competence motivation. Competence motivation, to White, is an intrinsic motivation and has a deep physiological root and does not depend on culturally acquired achievement motivation. Doci and Ryan (1980) have demonstrated that intrinsically motivated behaviours are those behaviours that are motivated by the underlying need for competence and self-determination. They argued that these needs are innate and that the intrinsically motivated behaviour that derive from them are rewarding in and of themselves. These behaviours are performed in the absence of any apparent external reinforcement. The views from this theory suggest that learning experiences which are in consonant with student's level of competence help initiate and maintain a student's competence motive

\subsubsection{Curiosity Motivation Theory}

Closely linked to competence motivation is curiosity motivation theory. Berlyne (1960) has suggested that when a person is in a situation in which conflicting responses are possible, a curiosity drive is generated and the person is 
motivated to seek further information just to satisfy the drive. He further explained that there is an optimum level of arousal that is physiologically based. This he sees to be a function of the brain. Bruner (1983) was of the view that every individual has a "built-in-will" to learn; and it is only through intrinsic motivation that the will to pursue is sustained. He believed that the best example of intrinsic motivation is curiosity. This theory suggests that curiosity initiates selfreinforcement. This implies that students become motivated when they are made to discover their own knowledge and skills.

\subsubsection{Incentive Motivation Theory}

Educators all over the world have used various techniques in motivating their students to learn. Provision of incentives or incitements seems to be the commonest being used. Cascio (1989) contended that when incentives or rewards purported to incite an individual fits the situation, performance increases an average of 30 per cent because of strong motivation. He also held the view that incentives directed towards a group increases motivation by 18 per cent. According to Porter and Lawler (1988) instead of working motivation being a determinant of performance, a performance of a task can provide motivation. Their view is that when the individual's skills and morale are improved he or she will be more committed to the task. Improved skill level makes performance of a task easier and enjoyable to the individuals. He or she will be more committed to the task Improved skill level makes performance of a task easier and enjoyable to the individuals. He or she thus gets satisfied with his or her own abilities and is spurred to do much better on the task. From the above views, it could be inferred that incentives increase people's motivation toward the performance of tasks. This implies that incentives or rewards play a very significant role in the student's learning process.

\subsubsection{Social Forces and Motivation}

Series of studies have revealed that social forces affect achievement motives. Among these social forces are attitude of parents to education and parental level of education.

According to Coleman (1988), the socio-economic status of parents has been found through studies by some scholars to have influence on the educational attainment of their children. He contends that social capital is a more dominant factor in influencing educational attainment. He refers to social capital as the quality of social interaction students derive from parents, relatives and community members. It also includes the quality of educational information and reinforcement received from the home and the neighborhood. Furthermore, it is the amount of interest and support parents invest in their children's education. Therefore, for children to be able to attain high level in education their parents should have quality social interaction with them. Also, if the family is educogenic, every effort will be to provide the children with all the materials they will need in their education. Children who come from educogenic families usually do well in school since their parents put pressure on them to take their studies seriously

\subsection{Parental Education}

Numerous studies have come to support the idea that parents' education influences their children's educational attainment (Teevan and McGhee, 1972). For children of parents of higher educational attainment do not only have greater access to education, they are able to avail themselves more often in educational attainment. Banks (1968) observed that the more highly educated the parents, the more likely they are to serve as positive role models. Such parents influence their children's aspirations for advanced schooling. They spend more quality time with their children and actively increase the academic abilities and opportunities of their children. The children from these families are likely to have supportive, rewarding educational experiences. But children of less educated parents may be poor and children living in poor families may drop out of school to seek employment to supplement their family income. This sometimes leads to creation of street children in the cities. According to Agyeman (1986), it is true to say that poverty negatively affects the chances of success of a child in school. For a child who is constantly hungry will find difficulty in giving full attention to a lesson in the classroom. Again, if a child observes that his or her parents or older siblings are either unemployed or in poorly paid jobs, he or she is likely to develop negative attitudes towards schooling.

\subsection{Motivation and Learning}

Motivation is often tied to other factors that influence energy and direction of behaviour in students learning. These are factors such as interest, need, value, attitude and aspiration. A student with an interest in a subject tends to pay attention to it. Such a student enjoys dealing with that subject either for what it can lead to or for its own sake and his attention level is high, his work output is sustained and his satisfaction is great. Also, a need for achievement can be satisfied by success in attaining a goal that requires effort. Likewise, a need for affiliation is satisfied friendly relationships with other persons.

Furthermore, a student's attitude to something consists of feeling for or against what he conceives that thing to be. For instance, if a student likes the subject physics, it means that he gets pleasure from being involved in physics activities and hence he is more likely to seek out these activities for which he has positive attitude. Attitudes like motives, arouse and direct purposeful activity. Finally, a student's aspiration, which is his hope or desires for a certain kind of achievement, determines the amount of effort directed towards a given goal. Students with high level of aspiration have been known to put a lot of effort towards the goal they have set for themselves.

\subsection{Nature of Curriculum and Motivation}

Woolnough (1997) has observed that the nature of science curriculum and student's motivation for high educational attainment are correlated. He was of the view that the nature of the science curriculum as a significant 
influence on the learner's performance in science. He further explains that when the science curriculum appears too difficult, too dull, too much like a hard work and too theoretical and impersonal it tends to "switch off" students with low intellectual and low need for competence and self-determination from doing science. He however, observed that for some students, traditionally the able and intellectually competent and motivated ones, and the same curriculum served as intrinsic motivational factor for high attainment in science.

\section{Materials and Methods}

\subsection{Study Area and Selection}

The study was conducted in the Wa District of the UWR of Ghana due to limited choice of science courses among JHS graduates in the Region. Five science and technology career related departments were purposively selected as units of data collection points. This method was deemed appropriate for the selection the nature of the study required a certain defined group of personalities who have chopped some success in the fields of science and could provide relevant information for the study. Table 2 shows the selected departments, number of respondents selected from each department and percentage distributions of the respondents from each department

\begin{tabular}{|c|c|c|c|}
\hline Departments & \multicolumn{2}{|c|}{ Number of Respondents } & $\begin{array}{c}\text { Percentage } \\
\text { Distribution }\end{array}$ \\
\hline & Male & Female & \\
\hline Government Hospital & 5 & 1 & 15 \\
\hline Private Hospitals & 2 & - & 5 \\
\hline Ghana Education Service & 24 & 2 & 65 \\
\hline Public Works Department & 2 & - & 5 \\
\hline Electricity Company of Ghana & 3 & 1 & 10 \\
\hline Total & 36 & 4 & 100 \\
\hline
\end{tabular}

Table 2: Selected Departments, Number of Respondents and Percentage Distributions

\begin{tabular}{|c|c|c|}
\hline Setting & Number Of Respondents & Percentage Distribution \\
\hline Urban & 23 & 57.5 \\
\hline Rural & 17 & 42.5 \\
\hline Total & 40 & 100 \\
\hline
\end{tabular}

Table 3: Distribution of Respondents by Rural and Urban Settings

\subsection{Study Design}

The study was a cross-sectional survey which sought to investigate the antecedent factors that have motivated some personalities to become successful in the fields of science. The research design used was quantitative approach. This approach was employed because it offers rich descriptive reports of participants' perceptions, attitudes, beliefs, views and feelings as well as the meanings and interpretations of the issue under investigation (Creswell, 2012).Data was collected from 40 successful science-achievers who were purposively drawn from five science related departments. The main instrument for data collection was structured questionnaire. This instrument was found to be more appropriate because it allowed respondents to be reached within a short period of time. Items on the questionnaire guide were in 4 parts. Part 1 was designed to collect information on respondents' demographic characteristics, educational background, ranks, qualification, present job, parental education and occupation. Part 2 was also designed to solicit information on respondents' choice of science and the rationale for the choice, the factors which motivated them to become successful in the fields of science, and views on ways to encourage students to read science at the JHS level and beyond. Part 3 of the questionnaire was designed to elicit information from respondents on role model and its influence in their achievement in science. Items on the last part (part 4) of the questionnaire were designed to collect information from the respondents on challenges they encountered during their educational careers and how they managed such challenges. To ensure the validity and reliability of the questionnaire items, extensive literature was reviewed and ideas were solicited from colleagues. Again, items on the questionnaire guide were vetted by experts to ensure its face validity, completeness, accuracy, contrast and uniformity. Finally, the questionnaire was pilot tested to evaluate its reliability for the main research. The questionnaire was then administered to the respondents at their various offices. This direct administration of the questionnaire help explain certain items further to the respondents when the need arose. This procedure did not only provide a higher proportion of usable responses but it also resulted to high return rate. A total of 40 questionnaires were returned and fully completed giving return rate of approximately $89 \%$.

Quality control measures such as the need for independent completion of the questionnaires were followed. This was to eliminate social desirability issues from the responses. This procedure was replicated throughout the administration of the questionnaires in all the departments.

\subsection{Data Analysis}

Statistical package for Social Sciences (SPSS) version 20 (IBM) software (SPSS Inc. Chicago,IIlinois, USA) was used to analyze the data. The researcher reviewed all the forms completed each day, checked for completion, and other errors. The data collected on each variable using the questionnaires were then coded and entered into the SPSS software version 
20 (IBM) after they have been cleaned and checked for completeness and consistencies against the items on the questionnaire guide. Cross-tabulation was conducted to determine the percentage distribution of responses of independent variables in the sample. One-Way ANOVA test was then conducted to establish any mean difference between independent variables in the sample. Data was then represented on graphs using excel.

\section{Results}

\subsection{Rural and Urban Motivational Factors}

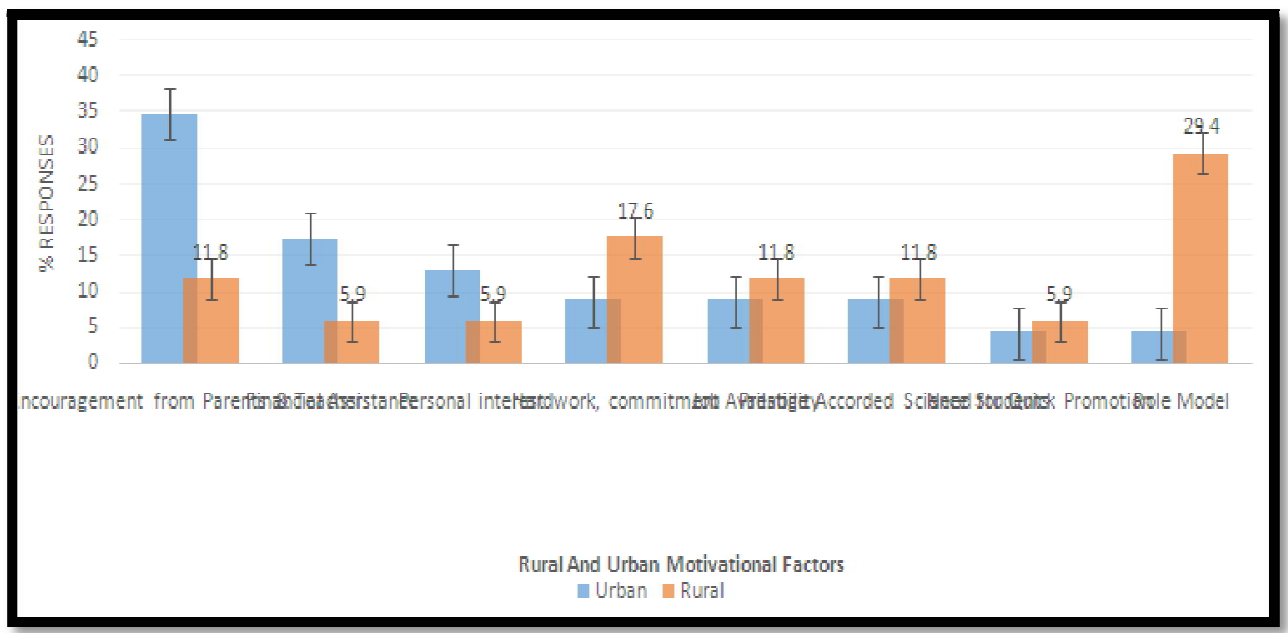

Figure 1: Rural and Urban Motivational Factors

Analysis of variance shows significant difference between rural and urban motivational factors ( Mean square $=1.469 ; F=6.723 ; p=$ 0.013).

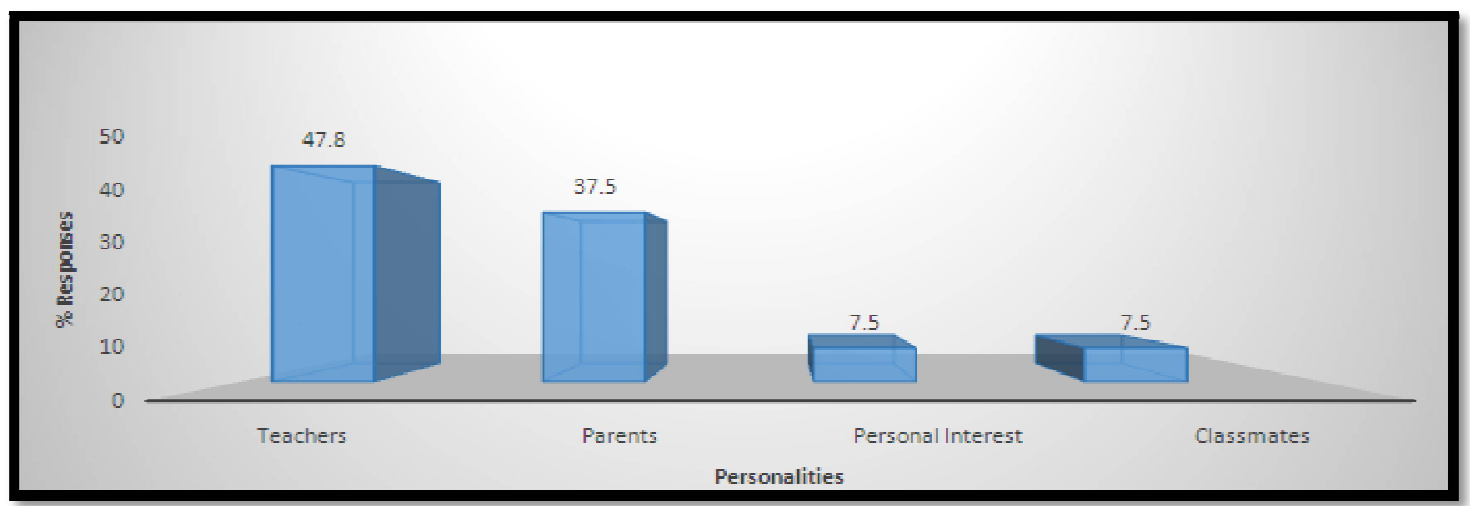

Figure 2: Personalities Who Influence Choice of Science

Analysis of variance shows significant difference between personalities who influence choice of science (mean square $=17.778 ; \mathrm{f}=49.231 ; \mathrm{p}=0.000$ ).

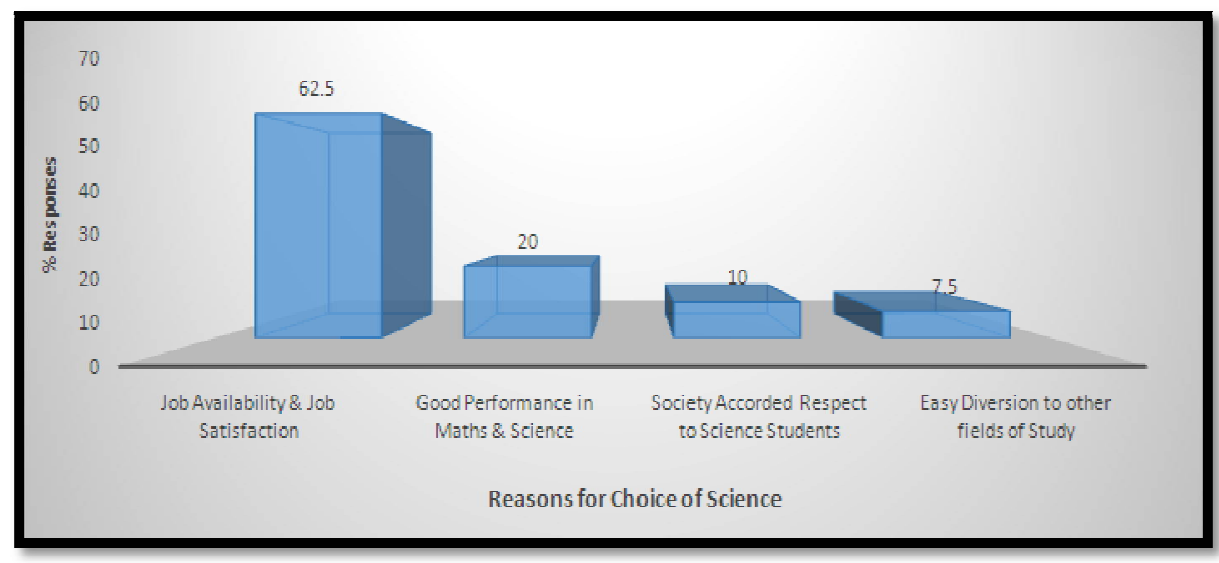

Figure 3: Reasons for Choice of Science 
Analysis of variance shows significant difference between reasons for choice of science (mean square=20.069; $F=49.828$; $\mathrm{p}=0.000)$.

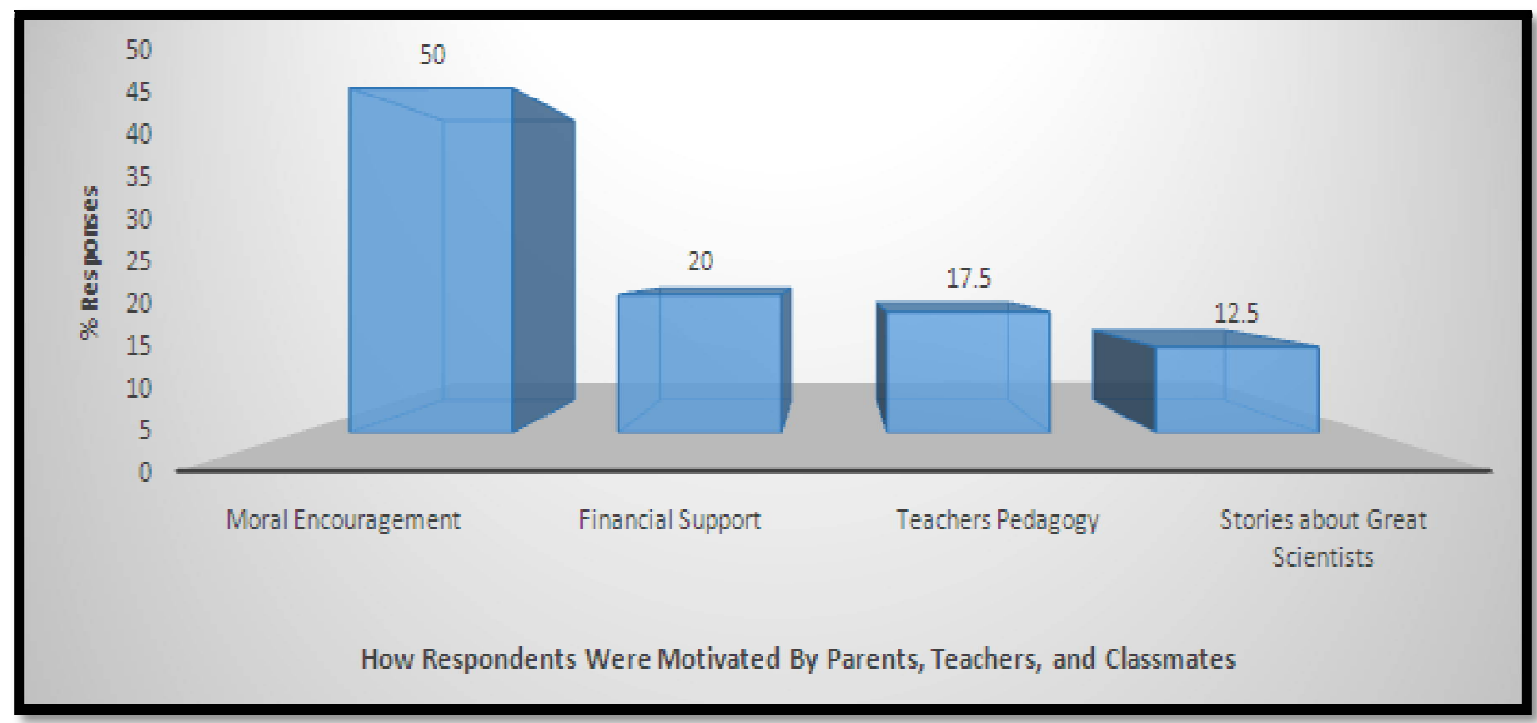

Figure 4: How Respondents Were Motivated by Parents, Teachers, and Classmates

Analysis of variance shows significant difference between how respondents were motivated by parents, teachers, and classmates (mean square=19.136; $F=26.310 ; p=0.000$ ).

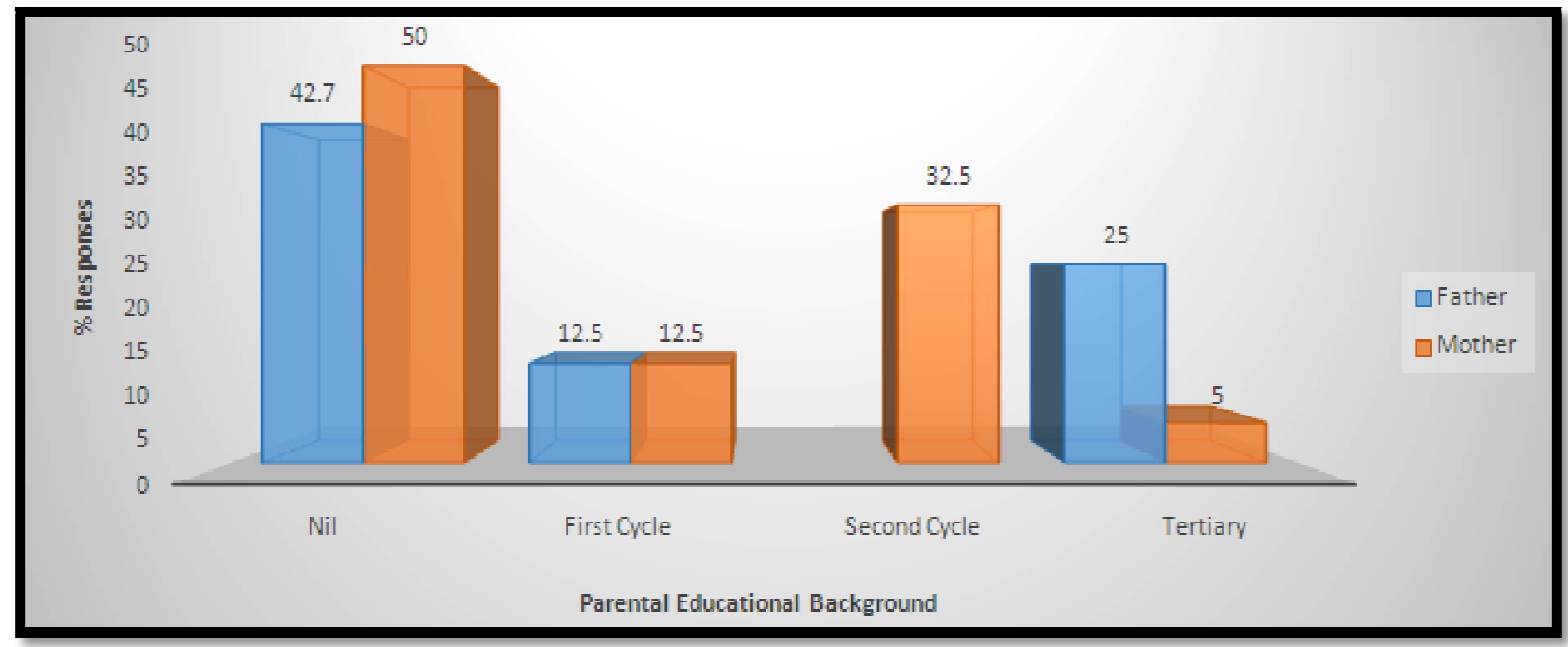

Figure 5: Parental Educational Background

Analysis of variance shows significant difference between parental educational background and motivation (mean square=13.225; $F=10.309 ; p=0.003$ ).

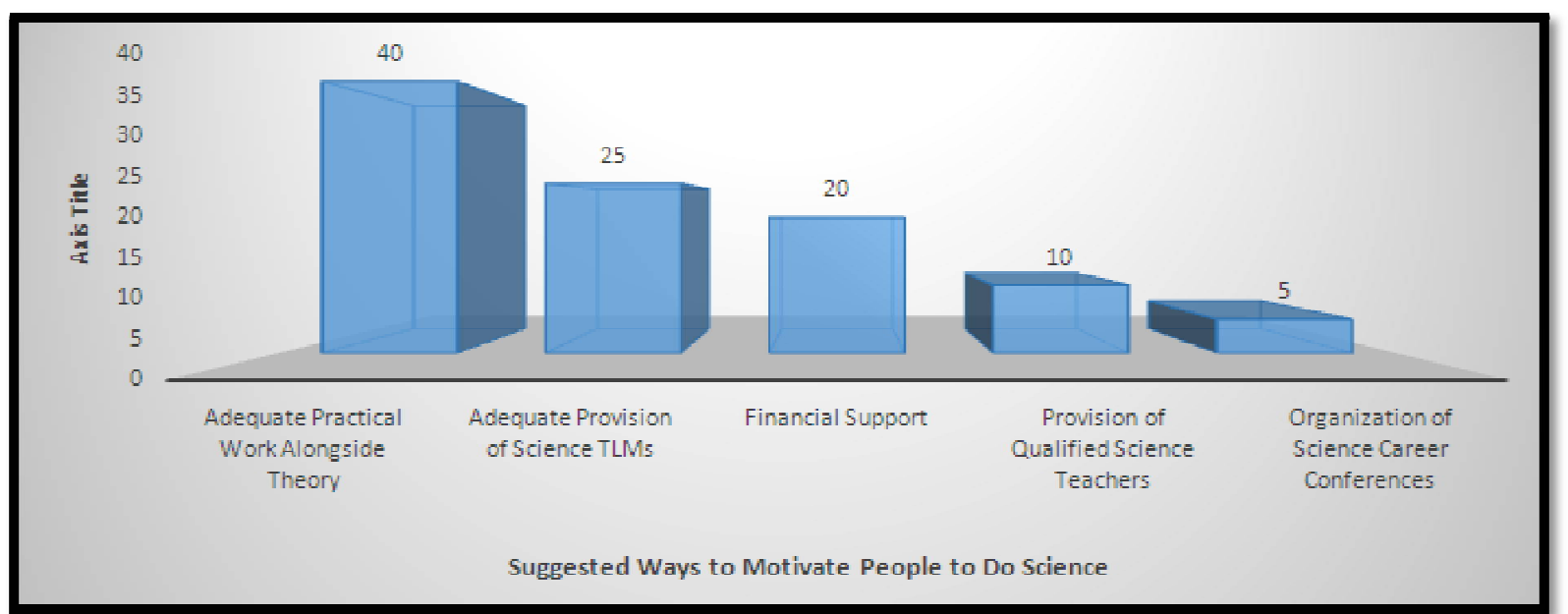

Figure 6: Suggested Ways to Motivate People to Do Science 
Analysis of variance shows significant difference between suggested ways to motivate students to read science (mean square $=24.544 ; \mathrm{F}=28.649 ; \mathrm{p}=0.000$ ).

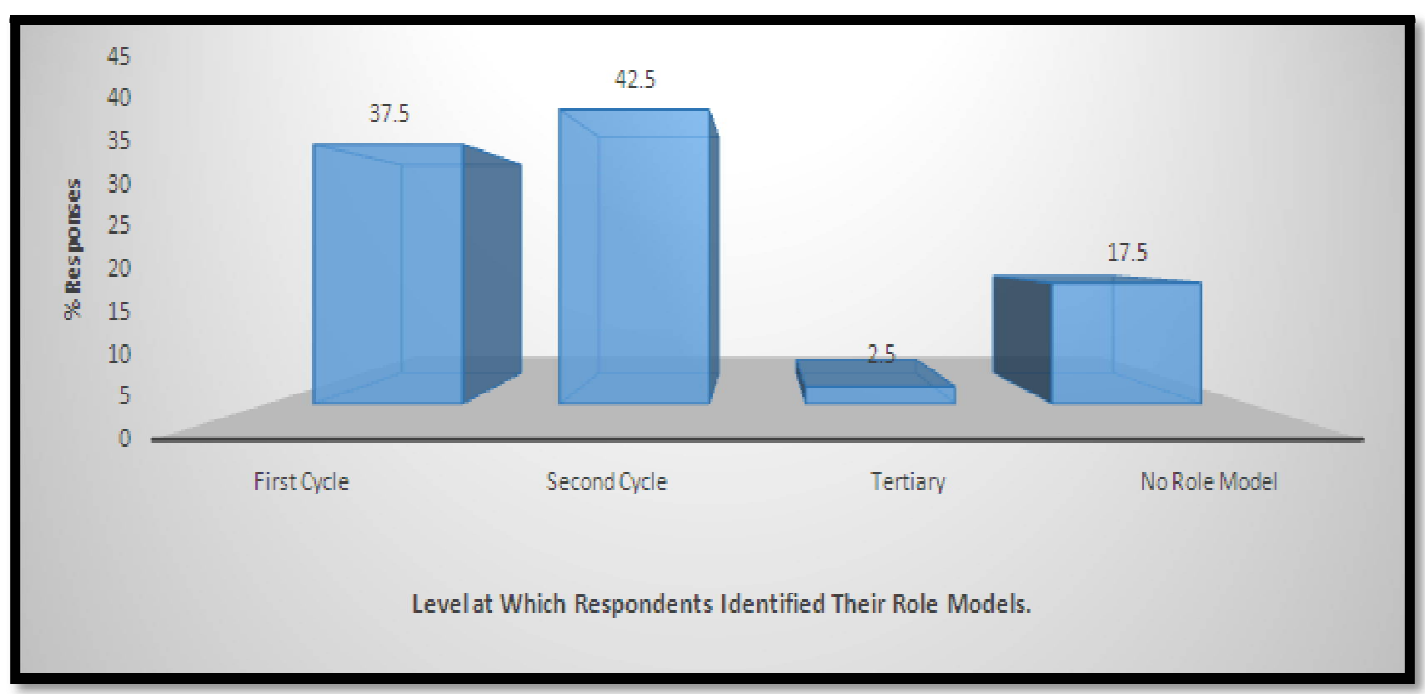

Figure 7: Level at Which Respondents Identified Their Role Models

Analysis of variance shows significant difference between levels at which respondents identified their role models (mean square=17.778; $\mathrm{F}=25.763 ; \mathrm{p}=0.000$ ).

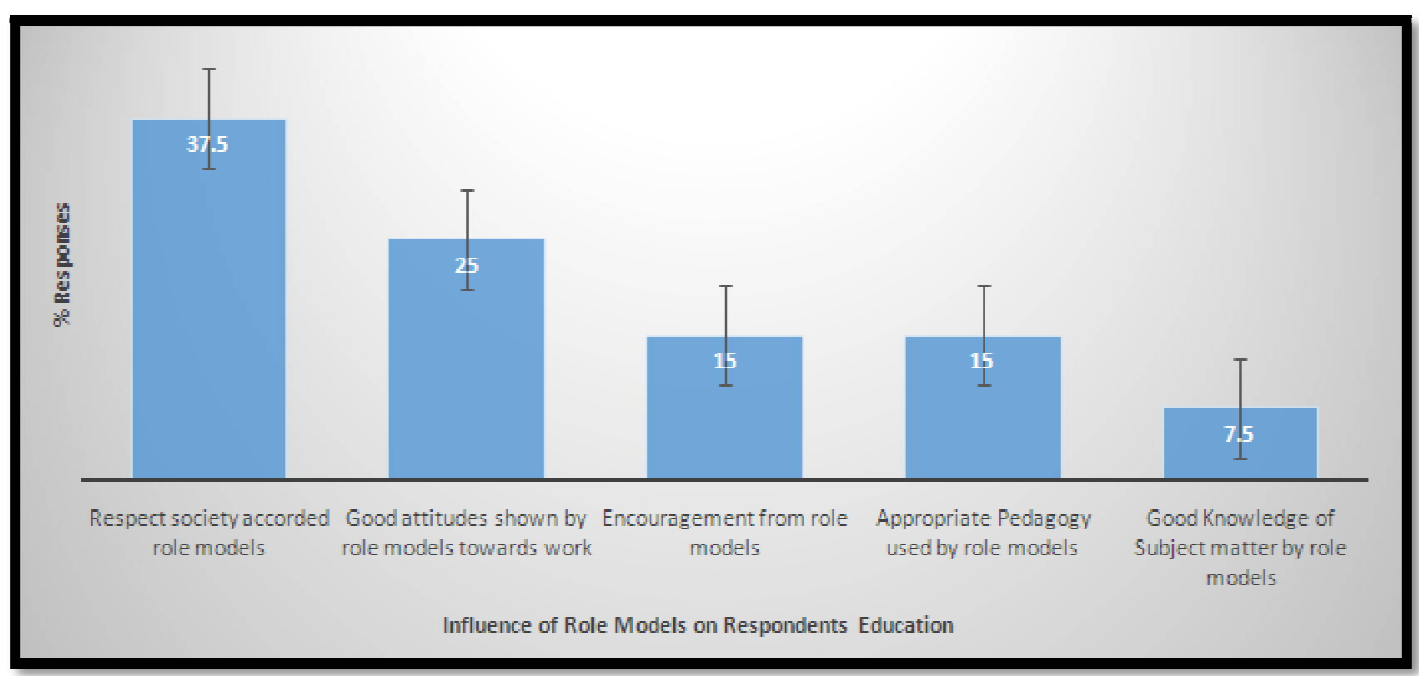

Figure 8: Influence of Role Models on Respondents Education

Analysis of variance shows significant difference between influence of role models on respondents education (mean square=26.678; $\mathrm{f}=24.298 ; \mathrm{p}=0.000$ ).

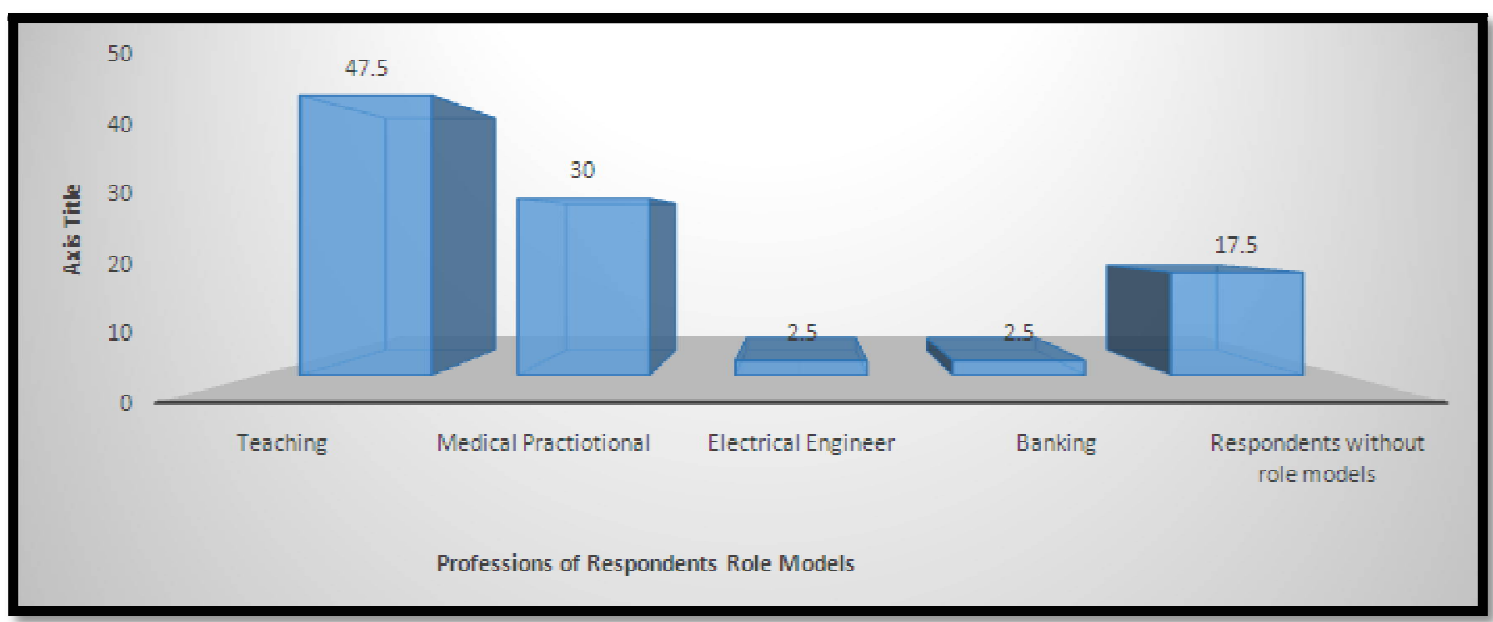

Figure 9: Professions of Respondents Role Models 
Analysis of variance shows significant difference between professions of respondents role models(Mean square=36.736; $F=28.128 ; p=0.000$ ).

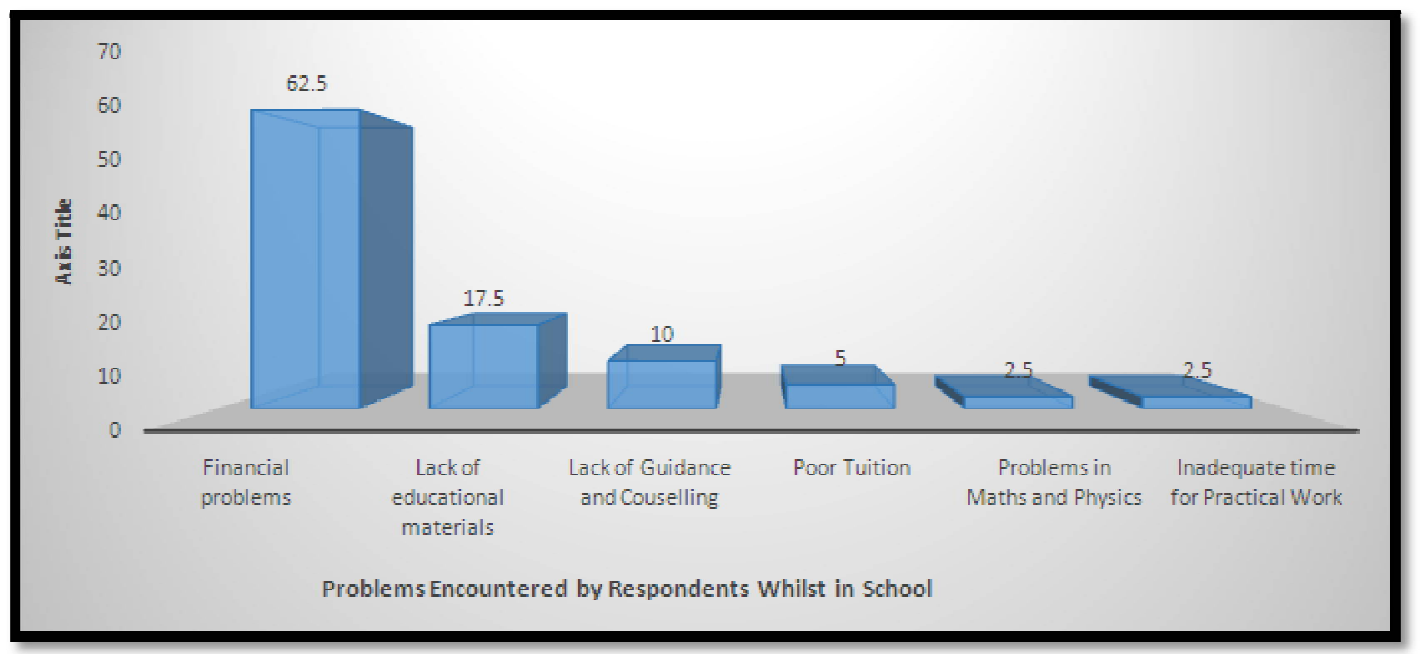

Figure 10: Problems Encountered by Respondents Whilst in School

Analysis of variance shows significant difference between problems encountered by respondents whilst in school (mean square $=34.225 ; \mathrm{F}=73.270 ; \mathrm{p}=0.000$ ).

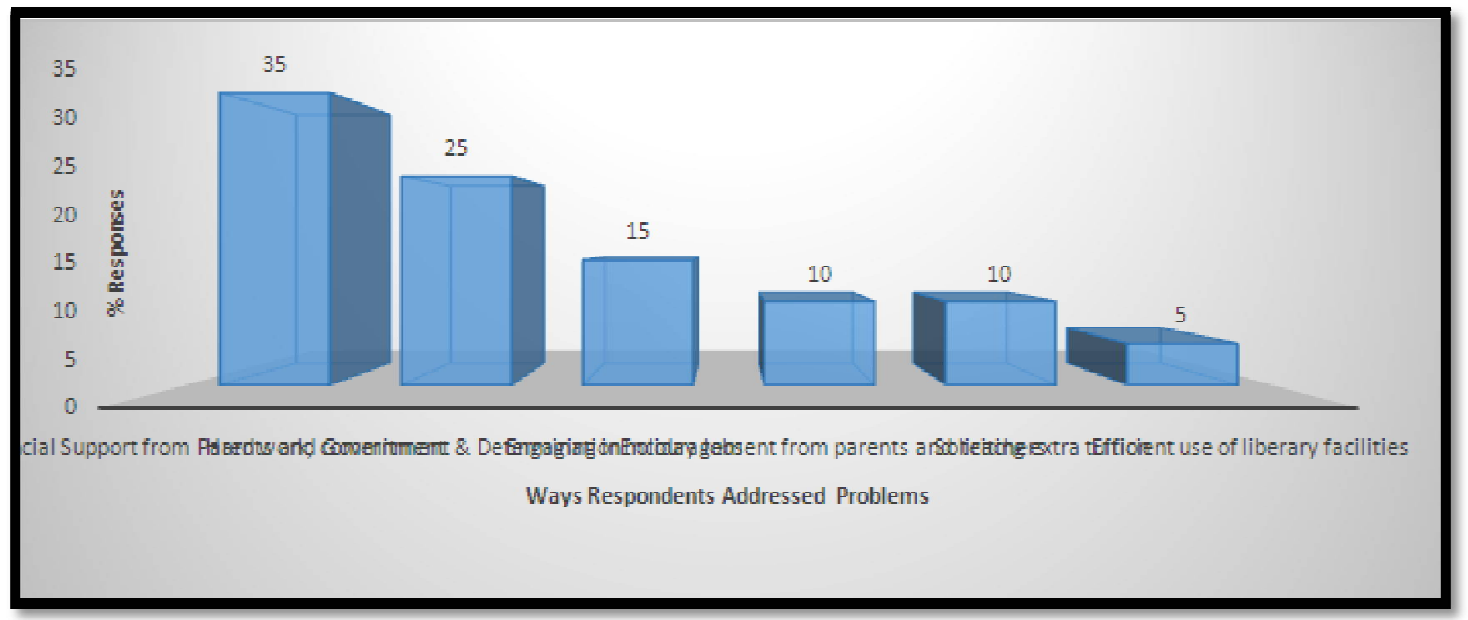

Figure 11: Ways Respondents Managed the Problems Encountered Whilst in School

Analysis of variance shows significant difference between ways respondents managed the problems they encountered whilst in school (mean square=40.00; $F=28.148 ; p=0.000$ ).

\section{Discussion}

The objective of this study was to find out the factors that have motivated some personalities to become successful in the fields of science and use the results to encourage more JHS graduates to opt for science courses. The result of this study shows that encouragement from parents and teachers constitutes the main factor motivating pupils from urban areas to read science. Eight (34.8\%) of the respondents confirmed this (Figure 1). In the rural areas, the main factor motivating the people is role models. Over $29.4 \%$ of the respondents are in province of this factor. The second major factors motivating people from the urban and rural areas are financial assistance (17.4\%), hard work, commitment and determination (17.6\%), respectively. Also, while personal interest (13.0\%) constitutes the third motivational factor in the urban areas, the rural people are in favour of availability of jobs (17.1\%). Analysis of variance shows significant difference between rural and urban motivational factors (Mean square $=1.469 ; \mathrm{F}=6.723 ; \mathrm{p}=0.013$ ).

. There are many reasons why students think of teachers as role models. One of the biggest reasons is the desire to become a role model for students to look up to, to learn from, and to remember for the rest of their lives. According to Merton and Kaufman (2003) role models make things easier for students learning procedure and enables them in the maturation and progression of professional uniqueness. Nonetheless, social conglomerate and cultural values have an impact on the selection of role models (Haider et al., 2016). Role models are pivotal component of medical education because they empower student learning in the way to conduct yourself and cooperate with patient, co-workers, and others (Bridges et al., 2011; Durham et al.,2008; Van Graan et al., 2016).Multiple studies reported that role model reassures and persuade medical students for attaining knowledge, empathetic behavior with the patient, collaboration, reciprocation, admiration and finally to earn professional qualities. According to Merton (2003) role models make things easier for students learning procedure and enables them in the maturation and progression of professional 
uniqueness. He further opined that Social Corporation and cultural values have an impact on the selection of role models (Dudenhausen,2017). Role models are pivotal component of medical education because they empower student learning in the way to conduct yourself and cooperate with students, co-workers, and others (Bridges, 2011; Van Graan, 2016). Multiple studies reported that role model reassures and persuade students for attaining knowledge, empathetic behavior with the patient, collaboration, reciprocation, admiration and finally to earn professional qualities(Bridges et al., 2011).

This results indicate that over $84 \%$ of the respondents chose science because they were influenced by their teachers' and parents. Analysis of variance shows significant difference between personalities who influence choice of science ( mean square $=17.778 ; \mathrm{F}=49.231 ; \mathrm{p}=0.000$ ).

This shows that teachers and parents are the most influential personalities in the choice of science by students. This finding agrees with the one held by Woolnough (1997) that the role of the teacher in any teaching and learning process cannot be overemphasized. This is because for many students, teachers were the factors that inspired them to read science in schools. These factors, he said, relate to how teachers relate to individual students and give them personal support and encouragement. Their attitudes towards the subject and the way they approach their methods in the classroom develop students' interest in the subject. Multiple studies have also reported that role models are an indispensable factor in medical education since they simplify to develop knowledge of the medical student and help in the progress of professional individuality through the observation of their clinical teachers in the way they perform and interrelate with patients, co-workers, and others. Brownell, 2001; Prideaux et al., 2000). Another study established that role models render a critical role in influencing undergraduates to motive and improve their behavioral quality (Azer, 2005).

Also, the role of parents in the choice of subjects or courses by their wards cannot be overemphasized. This is because it is the parents who sponsor and support their children's education and therefore, have greater responsibility in determining their future career and hence the choice of courses.

The results presented in Figure2 show that job availability and job satisfaction constitute the key reasons for the choice of science. Over $62.5 \%$ of the respondents gave these reasons. Analysis of variance shows significant difference between reasons for choice of science (mean square=20.069; $F=49.828 ; \mathrm{p}=0.000$ ). This suggests that students could be influenced to do science if they are informed about job opportunities and job satisfaction associated with scientific endeavours. This view justifies the conjuncture proposed by Merton (2003). He was of the view that role models are pivotal component of medical education because they empower student learning in the way to conduct yourself and cooperate with patients, co-workers, and others. Multiple studies reported that role model reassures and persuade medical students for attaining knowledge, empathetic behavior with the patient, collaboration, reciprocation, admiration and finally to earn professional qualities (Burgess et al., 2015).

Multiple studies concluded that role models and hidden curriculum in medical education improves and augments knowledge, attitude, and practice toward more professional, additionally role model also influences learners dominantly to select their future career planning. [59-66] Role model at many occasion inspires their pupils to work in the primary and rural health care program (Coldwell, 1992; Petersdorf, 1992; Osborn, 1993). The other research struggled to identify the factors that stimulate medical student career planning and recognized that those medical students opted for generalist Physician also the inherent reason were role models (Osborn,1993; Linzer, et al., 1994). Another study identified that 90\% graduating medical students of McGill University School of Medicine, Canada had role models or model in their 5-6 years' bachelor program and the majority (63\%) of them had discussed and obtained necessary guidance from their role models (Wright,1997). Multiple studies (Ludmerer, 1999; Asghari, 2011) concluded that all teachers, lecturers, consultants, professors, interns, and residents of medical faculty should be conscious enough as they are "acting as role models for their students and confirm that they act professionally at all times and that, where practicable, they share their ethical dilemmas and the reasoning they apply in dealing with" (Asghari et al., 2011) patients.

Role modeling has been accentuated as an important instructional procedure in medical education. Evidence from results presented in Figure 2 shows that $50 \%$ of the respondents were motivated by their parents and teachers through moral encouragement. Analysis of variance shows significant difference between how respondents were motivated by parents, teachers, and classmates (mean square $=19.136 ; \mathrm{F}=26.310 ; \mathrm{p}=0.000$ ).

This finding is in consonant with the view held by Teevan and Mcghee (1972) that if parents react positively to success and if they are supportive and affectionate, they are likely to instill in their children the motivation to gain success. Also, according to Annoh (1989), a study has shown that parent's encouragement is an important motivational facto in children's performance in school. He explains that parents who show interest in their children's education and them encouragement do perform better than those whose parents do not show interest in their children's education. This findings thus suggests that students could be motivated to read science if they are reared in the atmosphere of peace and are given positive encouragement throughout their educational endeavour. Encouraging students to think for themselves. Treat your classroom like a group of individuals, and celebrate their diversity. Create activities and discussions that foster conversations and discovery about who they are, and how they can appreciate the differences between each other. This type of focus from time-to-time will build a stronger bond between your students. Also, an environment of trust will build, which can relax the atmosphere and help students focus more on learning. It's also important to help students understand the way they learn, and encourage them to explore those parts of themselves as well. A role model represents and transfers the capabilities and potentials of a physician "committed to ensuring the best care of our patients"(Frank et al., 2005). Moreover, role models are poles apart from mentors as they inspire and encourage and thereafter, clarify by example whereas mentors have a formal relationship with the student (Ricer, 1998). The affiliation among the role model and modelee is reasonably inimitable in medical education as it is reliant on the selections made by the modelee (Passi, et al., 2016). A role model represents and transfers the capabilities and potentials of a physician "committed to ensuring the 
best care of our patients" (Frank et al., 2005). Moreover, role models are poles apart from mentors as they inspire and encourage and thereafter, clarify by example whereas mentors have a formal relationship with the student (Ricer, 1998). The affiliation among the role model and modelee is reasonably inimitable in medical education as it is reliant on the selections made by the modelee (Passi, 2016).

Considering the educational background of parents' the results presented in figure 4 shows that $42.5 \%$ of the respondents' fathers did not received any formal education. However, about $45 \%$ of them had formal education to second and tertiary levels, whilst less than $13 \%$ had formal education up to first cycle. In the case of the respondents' mothers, $50 \%$ of them had no formal education whilst the rest (50\%) received formal education up to first, second and tertiary levels. Analysis of variance shows significant difference between parental educational background and motivation (mean square=13.225; $F=10.309 ; p=0.003$ ).

The fact that the greater number of respondents had parents with high standards of formal education suggests why they were able to attain high educational standard. Studies showed that the higher the educational background of the parents, the more they influence their children's education positively. This observation thus agrees with the view held by Banks(1968) that the more highly educated the parents are the more likely they are to serve as positive role models for their children and that such parents influence their children's aspiration for advanced schooling. They spend more quality time with their children. They actively increase the academic abilities and opportunities of their children because high socio-economic status families usually live in more affluent communities with their financed schools. Children from these families are likely to have supportive and rewarding educational experiences. But children of less or no educated parents may be poor and living in poor families may drop-out of school to seek employment to supplement their family income.

The results presented in figure 5 shows that the major factor that could be used to motivate people to read science is adequate practical work alongside the theory. Over $40 \%$ of the respondents suggested that this. Also, adequate provision of teaching and learning materials and financial support to science students are other means suggested for motivating people to read science. Analysis of variance shows significant difference between suggested ways to motivate students to read science (mean square $=24.544 ; \mathrm{F}=28.649 ; \mathrm{p}=0.000$ ).

The results therefore imply that if more practical work are organized and directed so that students have personal experience of genuine problem solving projects, it will motivate them to read science to higher level.

The results presented in figure 6 shows that over $80 \%$ of the respondents have role models and these they identified at the first and second cycles. However, $7(17.5 \%)$ of the respondents have no role models. The fact that the majority of the respondents have models is an indication that role models are relevant in science education. Analysis of variance shows significant difference between levels at which respondents identified their role models (mean square=17.778; $F=25.763 ; p=0.000$ ).

This finding agrees with the view held by Campbell (1985) that people strive to achieve a level that other people who are close to them have achieved. Also, children at the basic school are at their formative stage and when they acquire values and form attitudes and habits, such characteristics go a long way to determine their future motives. It is therefore very important to say that if students are to do science, they need to be introduced to role models at their early stage so that they emulate the behaviour and aspirations of such role models. A study (Azer, 2005) established that role models render a critical role in influencing undergraduates to motive and improve their behavioral quality.

Data presented in figure 7 shows that the two major influences of role models on respondents education are the respect society accorded them and the positive attitude they show towards work and people. Over $62 \%$ of the responses given by the respondents are in province of these factors. Other characteristics shown by the role models which influenced respondents' education include encouragement, appropriate teaching and learning strategy and good knowledge of the subject matter. Analysis of variance shows significant difference between influence of role models on respondents education (mean square=26.678; $\mathrm{f}=24.298 ; \mathrm{p}=0.000$ ).

The data presented in Figure 8 shows that teachers are the main personalities serving as role models for students $(47.5 \%)$. Besides, $30 \%$ of the respondents have medical practitioners as their role models. Analysis of variance shows significant difference between professions of respondents role models (Mean square $=36.736 ; F=28.128 ; p=0.000$ ).

This result confirmed the view held by Annoh (1987). He was of the view that the teachers status is recognized as fundamentally important because of the amount power he holds in society. He further explains that the teacher is the house wife of culture-the one concerns with maintenance and continuity and hence conservation. He plays the role of trainer of children. But for most of all, he is the guardian of morals and the controller of conduct, and it is this status that he is remembered by all adults from their own childhood. The result therefore suggests that more student could be motivated to do science if teachers lead exemplary life. Multiple studies (Ludmerer, 1999; Asghari, 2011) concluded that all teacher, lecturers, consultants, professors, interns, and residents of medical faculty should be conscious enough as they are "acting as role models for their students and confirm that they act professionally at all times and that, where practicable, they share their ethical dilemmas and the reasoning they apply in dealing with" (Asghari et al., 2011)

The results in Figure 9 showed that majority (62.5\%) of the respondents faced financial challenges. Analysis of variance shows significant difference between problems encountered by respondents whilst in school (mean square $=34.225$; $F=73.270 ; p=0.000$ ).

This finding agreed with the view held by Agyeman (1986) that poverty negatively affects the chances of success of pupils' schools. He explains that a pupil who is constantly hungry will have difficulty paying attention in class and this affects his or her performance and thus lowers his or her educational attainment. This suggests that students could be motivated to read science if they are supported financially.

Evidence from the data presented in Figure 10 showed that 24(60\%) of the respondents managed the problems they encountered through financial support from parents, government and through their own hard work, commitment and 
determination. Also, the data showed that through holiday jobs, encouragement from parents and teachers and the use of library facilities, $40 \%$ of the respondents were able to overcome their problems. Analysis of variance shows significant difference between ways respondents managed the problems they encountered whilst in school (mean square $=40.00$.; $\mathrm{F}=28.148 ; \mathrm{p}=0.000$ ).

This findings suggests that students could be motivated to read science to higher grades if they are supported financially and as well as through hard work, commitment determination.

\section{Conclusion}

From the study, it is evidence that students from urban and rural settings of the study area have different motivational factors enabling them to read science. Whilst role models are found to be dominant factor in the rural areas, encouragement from the school community dominates the urban settings. Also, job satisfaction associated with scientific endeavors are the main factors motivating students to read science. Besides, the relevance of science in other fields as well as good performance in mathematics and science constitute other variables motivating people to pursue science courses. Furthermore, it is evince that teachers and doctors are the personalities motivating people to read science. The major problems that confronted the personalities include poverty, inadequate tuition, unavailability of teaching and learning materials and insufficient equipment for practical work. The personalities were able to overcome their problems through hard work, commitment, self-sacrifice and determination; soliciting financial support from parents, relatives and the government; hiring their labour for money after classes and during holidays; borrowing educational materials from friends and making efficient use of limited library facilities in their communities.

\section{Recommendation}

Based on the findings of the study, the following are recommendations to encourage many students at presecondary level to opt for science courses and pursue them to the tertiary level.The study recommends that since parents and teachers are the personalities influencing students' choice of science, the two parties must play a collaborative role in such activities. Here, teachers have added role to play. They are to make data on students' performances, their aspirations and interests available to parents so that they would have concrete basis and upon which they can base their decisions when helping their wards to choose courses. Besides, the evident that job satisfactions associated with science are the factors "switching" students on science is an indication that students thus need self-awareness on carrier information to enable them make an informed and valid decisions on their future careers. This then, suggests to the guidance and counselling coordinators to intensify their career guidance services in all the educational levels, particularly the JSS because at this level, the students are expected to select course they will do at the SSS level.

Additionally, since it is the role models influencing people in the rural areas to read science, the study recommends that those personalities whose positive images are influencing students to read science lead an exemplary life. Again, it is recommended that the specific jobs that are associated with science and require scientific knowledge and skills, and which are appealing to students interests and aspirations need to be identified and the requirement for one to be employed into such jobs be made known to the students early enough. This will enable them channel their efforts towards the meeting these requirements.

Furthermore, the study also discovered that parents' educational background influences their children's education. It is thus recommended that parents should try and have quality social interaction with their children. They should also make available to their children quality educational information and experiences and incentive packages.These will motivate them to put extra efforts towards their schooling. Because of the varied socio-economic hardships prevailing now many parents are not in a position to sponsor their children's science education, though some of these children may have good background in science. It is therefore recommended that a scholarship scheme be instituted for such students by the government to enable them develop their talent in science.

Finally, the observation that students faced problem of poor tuition is an indication that there are science teachers in some of these schools who have weak background in science. The study recommended that such teachers should be identified and in-service courses organized for them to enable them upgrade their knowledge in science. Besides, the study also revealed that some schools are plagued with inadequate teaching and learning materials. It is thus recommended that such schools be identified and funds provided for the purchase of such needs.

\section{Acknowledgement}

The authors are deeply grateful to the staff of Education, Health, PWD, Agriculture and Electricity Company of Ghana all of Wa District of the Upper West Region of Ghana for their support and contribution to the success of this study.

\section{References}

i. Allen, L. (1973). An examination of the ability of third grade children from the science curriculum improvement study to identify experimental variables and to recognize change. Science Education, 57 (1), 123-151.

ii. Allen, R.E (1985). The Oxford Dictionary of Current English (7th, ed.), New York, Oxford University Press.

iii. Andersen, P., \&Vandehey, M. (2012).Career counseling and development.2nd edition, United States of America: Brooks/ Cole.

iv. Blandford, S., \& Knowles, C. (2009).Developing professional practice 0-7. England: Pearson Education Limited.

v. Annoh, E.K. (1989). Education, Kumasi, Cita Printing Press Ltd.., Page 64.

vi. Asghari F, Fard NN, Atabaki A. Are we proper role models for students? Interns' perception of faculty and residents' professional behaviour. Postgrad Med J 2011; 87 (1030): 519-23. 
vii. Asghari F, Fard NN, Atabaki A. Are we proper role models for students? Interns' perception of faculty and residents' professional behaviour. Postgrad Med J 2011; 87 (1030): 519-23.

viii. Atkinson, R.E. (1964). Introduction to Psychology, New York, Harcourt, Brace, Jovanovich Inc.

ix. Azer SA. The qualities of a good teacher: how can they be acquired and sustained? J R Soc of Med. 2005; 98(2): 6769.

x. Bridges DR, Davidson RA, Odegard PS, and Maki IV, Tomkowiak J. Interprofessional collaboration: three best practice models of Interprofessional education. Med Educ Online. 2011; 16: 10.3402/ Meo.v16i0.6035.

xi. Bridges DR, Davidson RA, Odegard PS, and Maki IV, Tomkowiak J. Interprofessional collaboration: three best practice models of interprofessional education. Med Educ Online. 2011; 16: 10.3402/ Meo. v16i0.6035.

xii. Brophy, J. (2010). Motivating students to learn. 3rd edition, United Kingdom: Routledge.

xiii. Brownell AK, Cote L. (2001) Senior residents' views on the meaning of professionalism and how they learn about it. Acad Med 2001; 76(7): 734-7.

xiv. Bruner, J. (1960). The Process of Education. Cambridge, MA: Harvard University Press.

xv. Carin, A., \& Bass, J. E. (2001).Teaching science as inquiry. 9th edition, New Jersey: Prentice-Hall, Inc.

xvi. Cowan, J. (1988). On becoming an innovative university teacher: reflection in action. UK: Open University.

xvii. Bruner, J.S. (1983. Towards a Theory of Instruction, Cambridge, Mass. Harvard University Press.

xviii. Cascio, W.F. (1989. Managing human resources, New York, McGraw-Hill, Inc.

xix. Chauhan, S.S. (1978). Advanced Educational Psychology, New York, Vikas Publishing House, Pvt. Ltd.

xx. Coleman, J.S. and Associates, (1966). Equality of Opportunity, Washington D.C., US Department of Health, Education and Welfare.

xxi. David Fulton Publishers Ltd. Kolb, D. A. (1984).Experiential learning: Experience as the source of learning and development. New Jersey: Prentice-Hall.

xxii. diSessa, A.A. (2006), "A History of Conceptual Change Research", in R.K. Sawyer (ed.), The Cambridge Handbook of the Learning Sciences, Cambridge University Press, New York, pp. 265-281.

xxiii. Doci, E.L. and Ray, R.M. (1980). The Empirical Exploration of Intrinsic Motivational Processes. In Berkowitz (Ed). Advanced in Experimental Social Psychology. Vol. 13.

xxiv. Durham CF, Alden KR.(2008). Enhancing Patient Safety in Nursing Education Through Patient Simulation. In: Hughes RG, editor. Patient Safety and Quality: An Evidence-Based Handbook for Nurses. Rockville (MD): Agency for Healthcare Research and Quality (US); 2008 Apr. Chapter 51. Available at: https:/ / www.ncbi.nlm.nih.gov/ books/ NBK2628/

xxv. Ebel, R.L. (1980, February). The failure of schools without failure, Phi Delta Kappan. Vol. 6, pp386-388.

xxvi. Farrant, J.S. (1971). Principles and Practices of Education. Bristol, Western Printing Service, p207.

xxvii. Federal Aviation Administration, (2009).Aviation instructor's handbook. New York: Skyhourse Publishing, Inc.

xxviii. Fielding, M. (1994). Valuing difference in teachers and learners: Building on Kolb's learning styles to develop a language of teaching and learning. Curriculum Journal, 5(3) 393-417.

xxix. Ghartey-Ampiah, J., Tufuor, J. K., \& Gadzekpo, V. P. Y. (2004) Teachers' views on the role of science practical activities in the teaching of science in Ghanaian senior secondary schools. African Journal of Educational Studies in Mathematics and Sciences, 2 (2) 1-9.

xxx. Ghazaryan, M. (2008).References for importance of hands-on activities in learning. Retrieved from http:/ / www.mass.edu.lb/ PAPER\%20ON\%20HANDS\%20ON\%20LEANRING.pdf.

xxxi. Gibbs, G. (1988). Learning by doing: A guide to teaching and learning methods. UK: Liverpool Hope University College.

xxxii. Gorard, G. (2004). Combining methods in educational and social research. Berkshire: Open University Press.

xxxiii. Healey, M., \& Jenkins, A. (2000) Kolb's experiential learning theory and its application in geography in higher education. Journal of Geography, 99 (5) 185-195.

xxxiv. Hummel, R. and Sprinthall, N. (1965). Underachievement related to interest, attitudes and values. Personal and Guidance Journal, 44, pp388-395.

xxxv. In K. Crowley, Schunn, C. D., \& Okada, T. (Ed.), Designing for science: Implications from professional, instructional and everyday science, Mahwah, New Jersey: Erlbaum. IOJPE ISSN: 1300 - 915X www.iojpe.org International Online Journal of Primary Education 2014, volume 3, issue 1 Copyright @ International Online Journal of Primary Education.

xxxvi. Ingule, O.F. (1996). Introduction to Educational Psychology, Brick, Court, Grove Westland, Nairobi, East African Educational Publishers, Ltd. IOJPE ISSN: 1300 - 915X www.iojpe.org International Online Journal of Primary Education 2014, volume 3, issue 1 Copyright @ International Online Journal of Primary Education 39.

xxxvii. James H. \& McMillan (2008).Educational research: Fundamentals for the consumer. 5th edition, United States: Pearson Education.

xxxviii. Jindrich, S. (1998). References forhow do children develop? Retrieved from

xxxix. http:/ / www.gdrc.org/ kmgmt/ learning/ childlearn.html.Kaufman MT. Robert K. Merton, Versatile Sociologist and Father of the Focus Group, Dies at 92. The New.

xl. Klahr, D., Chen, Z., \& Toth, E. E. (1999). From cognition to instruction to cognition: A case study in elementary school science instruction.

xli. Kolb, D. A., Boyatzis, R. E., \& Mainemelis, C. (1999). Experiential learning theory: Previous research and new directions. Cleveland: Department of Organizational Behaviour, Weather head School of Management and Case Western Reserve University. 
xlii. Linzer M, Slavin T, Mutha S, Takayama JI, Branda L, VanEyck S, McMurray JE, RabinowitzHK.(1994). Admission, recruitment, and retention: finding and keeping the generalist-oriented student. J Gen Int Med 1994; 9(Suppl 1): S14-23.

xliii. Linn, M.C. (2006), "The Knowledge Integration Perspective on Learning and Instruction”, in R.K. Sawyer (ed.), The Cambridge Handbook of the Learning Sciences, Cambridge University Press, New York, pp. 243-264.

xliv. Ludmerer KM. (1999). Instilling professionalism in medical education. JAMA 1999; 282 (9): 881-2.

xlv. MacLellan, D.C. (1965). Towards a Theory of motive acquisition. American Psychologist, Vol. 20, pp321-323.

xlvi. Maslow, A.H. (1954). Motivation and Personality. New York, Horper and Publishers, Ltd.

xlvii. McMurray A.J., Pace, R. W. \& Scott, D. (2004).Research: A common sense approach. Melbourne: Thomson. National Science

xlviii. Teachers Association, (2001).Practicing science: The investigative approach in college science teaching. Virginia: National Science Teachers Association Press.

xlix. Norman, W. (2005).End the biggest educational and intellectual blunder in history; a $\$ 100,000$ challenge to our top educational leaders. Florida: Scientific Method Publishing Co.

1. Ormrod, J.E. (1999). Human learning. 3rd edition, New Jersey: Prentice Hall.

li. Osborn EH. (1993). Factors influencing students' choices of primary care or other specialties. Acad Med 1993; 68 (7): 572-4.

lii. Overbaugh, R. (2004). An overview of Jerome brunner his theory of constructivism, United States: Old Dominion University. Retrieved from

liii. http:/ / www.odu.edu/ educ/ roverbau/Class_Websites/ 761_Spring_04/ Assets/ course_docs/ID_Theory_Reps_Sp04 / BrunerCherry.pdf

liv. Piaget, J., \& Inhelder, B. (1969).The psychology of the child. New York: Basic Books.

lv. Prideaux D, Alexander H, Bower A, Dacre J, Haist S, Jolly B, Norcini J, Roberts T, Rothman A, Rowe R, Tallett S. (2000). Clinical teaching: maintaining an educational role for doctors in the new health care environment. Med Educ 2000; 34(10): 820-6.

lvi. Rosenshire, B.V. (1980). How time is spent in an elementary classroom, Inc. Denhem and A. Literman (Eds), Time to learn. Washington D.C. National Institute of Education.

lvii. Shymansky, J. A., Hedges, L. V., \& Woodworth, G. (1990) A reassessment of the effects of inquiry-based science curricula of the '60s on student performance. Journal of Research in Science Teaching, 27, 127-144.

lviii. Stronge, J. H., Tucker, P. D. \& Hindman, J. L. (2004).Handbook for qualities of effective teachers. USA: Association for Supervision and Curriculum Development.

lix. Teevan, R.C. (1972). Childhood Development of Fear of Failure Motivation. Journal pp345-348.

lx. Tesser, A. \& Campbell, J. (1985). A self-evaluation Maintenance Model of Students Motivation, In, C.A. Ames and R. Ames, (Eds). Research on Motivation in Education: The Classroom Millieu, New York, Academic Press.

lxi. Thanasoulas, D. (2001). References for constructivist learning, ELT Newsletter, Article 54. Retrieved from http:/ / www.eltnewsletter.com/ back/ April2001/ art542001.htm.

lxii. Trowbridge, L.W. \& Bybee, R.W. (1990). Becoming a secondary school Science Teacher, Ohio, USA, Merrill Publishing Company.

lxiii. Van Graan AC, Williams MJS, Koen MP. (2016). Professional nurses' understanding of clinical judgement: A contextual inquiry. Health SA Gesondheid. 2016; 21: 280-293.

lxiv. Van Graan AC, Williams MJS, Koen MP. Professional nurses' understanding of clinical judgement: A contextual inquiry. Health SA Gesondheid. 2016; 21: 280-293.

lxv. Van Graan AC, Williams MJS, Koen MP. Professional nurses' understanding of clinical judgement: A contextual inquiry. Health SA Gesondheid. 2016; 21: 280-293.

lxvi. VanNoord, M. L. (2007). Identifying factors of motivation in adult learners returning to higher education in nursing. US: ProQuest Information and Learning Company.

lxvii. Wigfield, A., Eccles, J. S., \& Rodriguez, D. (1998).The development of children's motivation in school contexts.In P. D. Pearson, \& Iran-Nejad, A. (Ed.), Review of research in education. Washington, DC: American Educational Research Association.

lxviii. Wilson, R. (2008). References for Promoting the Development of Scientific Thinking, Early Childhood NEWS. Retrieved from http:/ / www.earlychildhoodnews.com/ earlychildhood/ article_view.aspx?ArticleId=409.

lxix. Woolnough, B. E. (1994). Effective Science Teaching. Milton Keynes: Open University Press.

lxx. Woolnough, B.E. (1997). Motivating Students or Teaching Pure Science, in school Science Review, UK. Oxford University Press, vol. 78, pp.67-71.

lxxi. Worth, K. (2010) Science in early childhood classrooms: Content and process. Massachusetts: Education Development Center, Inc. Retrieved from http:/ / ecrp.uiuc.edu/ beyond/ seed/ worth.html.

lxxii. Wright S, Wong A, Newill C.997). The Impact of Role Models on Medical Students. J Gen Intern Med 1997; 12 (1): $53-6$. 